\title{
循環調節因子に関する最近の進歩
}

\author{
岡 本 博, ${ }^{*, a}$ 松 村 靖 夫 $b$
}

\section{New Perspectives on Vasoactive Molecules Regulating Cardiovascular Function and Diseases}

\author{
Hiroshi OKAMOTO*,a and Yasuo MATSUMURA ${ }^{b}$ \\ ${ }^{a}$ Laboratory of Cardiovascular Pharmacology, Department of Biopharmaceutical Sciences, Kobe Gakuin \\ University, 1-1-3 Minatojima, Chuo-ku, Kobe 650-8586, Japan, and ${ }^{b}$ Laboratory of Pathological and \\ Molecular Pharmacology, Osaka University of Pharmaceutical Sciences, \\ 4-2-1 Nasahara, Takatsuki City 569-1094, Japan
}

日本人の死因の中で，心臓・脳血管系疾患の両方 を合わせた循環器疾患は約 $30 \%$ でり, 死因第一 位の癌を超えて高い割合を占めている。これは, 特 に最近の日本人にみられる生活習慣の欧米化を背景 とし，それに基づいた高血圧，糖尿病，高脂血症 と，それらを危険因子として発症する動脈硬化性疾 患によるところが大きい。ささ，血圧調節には多様 な循環調節因子が関与しており，高血圧症の大部分 を占める本態性高血圧はこれらの血圧調節異常によ って生じると考えられている。循環調節因子を，そ の伝達物質としての位置付けからみれば, 循環ホル モンや神経分泌因子, そして組織局所でパラクライ ン/オートクライン的に分泌・作用するオータコイ ド様因子などに分類することができる。しかし，ミ ネラロコルチコイド受容体が副腎以外の心血管系組 織にも存在することが確認されてきたように，新た な知見は続々と既成の概念を崩してきている，さら に，これら多様な因子は各因子間で相互に産生分泌 や作用を調節しあい，そのような因子間でのバラン スを取りながら循環器系組織に直接的あるいは間接 的に働きかけていることも明らかにされてきた。 そ して, 高血圧, 糖尿病あるいは高脂血症などの基礎 疾患による様々な臟器障害にも, 多くの循環調節因 子が複雑に係わつており，それらの関与を $1 つ 1 つ$ 明らかにする作業が，今後の優れた新規治療薬の開

$a$ 神戸学院大学薬学部生命薬学部門循環器薬理学研究室 （干 650-8586 神戸市中央区港島 1-1-3), $b$ 大阪薬科大 学病態分子薬理学研究室（干569-1094 高槻市奈佐原 4 -20-1)

*e-mail: okamotoh@pharm.kobegakuin.ac.jp 日本薬学会第 127 年会シンポジウム S19 序文
発，あるいは既存薬物のより有効な使用方法の発見 につながるであろう。

日本薬学会第 127 年会シンポジウム「循環調節因 子に関する最近の進歩」の目的としたことは, 個々 の循環調節因子の役割のみならず，それが他の因子 とどのように係わり，それによって正常な循環調節 がどのように行われ，その破綻によって循環器障害 がどのよう発症し，そして今後の治療薬開発にどう 係わるかについて, 講演者に最新の知見をご紹介頂 くことにありました，本誌上シンポジウムは，それ ら 7 名の講演者のうち 5 名の方々のご協力を得て, 学会当日の講演を聞き逃された読者にその詳細をご 紹介するものです。本特集には，順に次の循環調節 因子に関する内容が含まれ，いずれのご研究内容も 最新の知見を含んだ素晴らしいものであります．1） エンドセリンの急性腎不全や高血圧発症への関与 と, エンドセリン受容体遮断薬による治療効果, そ してエンドセリン産生を転写レベルで阻害する薬物 による病態改善効果について, 大阪薬科大学の大喜 多守先生に研究成果をご紹介頂いた，2）アルドス テロンによるミネラロコルチコイド受容体を介した 腎障害発症機構と酸化ストレスの役割について, 香 川大学医学部の西山 成先生に, そしてアルドステ ロンによる血管内皮の機能障害, 特に eNOS の活 性化抑制と uncoupling について, 東京大学大学院 医学研究科の長田太助先生に, それぞれ腎臓と血管 の両観点からご執筆頂いた。3）NO 合成酵素 (nNOS, eNOS, iiNOS) のトリプルノックアウトマ ウスを開発し, その phenotype 解析から一酸化窒 素（NO）の未知の役割について, 産業医科大学医 
学部の筒井正人先生にご執筆頂いた．4）アンジオ テンシン II の 2 つ受容体サブタイプのうち, タイ プ 2（AT2）受容体を介した血管弛緩機構と，それ へのブラジキニン $/ \mathrm{NO}$ 系の関与について, 神戸学 院大学薬学部の屋山勝俊先生にご執筆頂いた。な お，学会シンポジウムでご講演頂いた，宮崎大学医 学部の北村和夫先生（アドレノメデュリン）及び慶
応大学医学部の市原淳弘先生（プロレニン）は, 本 論文執筆に加わっておられない.

最後に, 今回ご紹介いただいた各種循環調節因子 の病態生理学的役割に関して, 読者各位の理解が深 まるとともに，今後の治療薬開発に向けてそれぞれ のご研究がさらに発展され，この分野の進歩に大き く貢献されることを期待する. 